\title{
Anesthetic recovery assisted by rope at three points in horses
}

\author{
Diego Rafael Palma da Silva ${ }^{1}$ Gabriele Biavaschi Silva ${ }^{2^{*}}$ \\ Flávio Desessards De La Côrte ${ }^{2}$ Karin Erica Brass ${ }^{2}$ Ricardo Pozzobon ${ }^{2}$ \\ Stefano Leite Dau $^{2}$ Diego de Gasperi ${ }^{3}$ Gabrielle Coelho Freitas ${ }^{4}$ C
}

${ }^{1}$ Medicina Veterinária, Clínica de Equinos Santa Maria, Santa Maria, RS, Brasil.

${ }^{2}$ Departamento de Clínica de Grandes Animais, Universidade Federal de Santa Maria (UFSM), Av. Roraima, 1000, 97105-900, Santa Maria, RS, Brasil. E-mail: gabibiavaschi@hotmail.com. "Corresponding author.

${ }^{3}$ Department of Surgical Sciences, University of Wisconsin, Madison, United States.

${ }^{4}$ Universidade Federal da Fronteira Sul (UFFS), Campus Realeza, Realeza, PR, Brasil.

\begin{abstract}
This study evaluated the quality of anesthesyc recovery of horses using a three-point assisted method. Sixty-eight horses (37 females and 31 males) of different breeds, age and weight submitted to general anesthesia for abdominal - ABD ( $n=15)$, arthroscopy - ART $(n=17)$, other orthopedic - ORT $(n=18)$ and miscellaneous - MIX $(n=18)$ surgical procedures. Isoflurane resulted in shorter recovery time (67.4 $\pm 25.7 \mathrm{~min})$ compared to halothane $(88.0 \pm 37.8 \mathrm{~min})$. The mean duration $( \pm S D)$ of anesthesia for ABD, ORT, ART and MIXgroups was 166.7 ( \pm 14 ), 54.9 ( \pm 5.9$), 86.5$ ( \pm 7.3$)$ and 76.4 ( \pm 32.5$)$ minutes (min) respectively. Quality of recovery wasn 't influenced by duration of anesthesia or by use of analgesic, sedative and/or anesthetic drugs or not $(p>0.05)$. Mean standing time $\left(T_{E s}\right)$ during anesthetic recovery was 67.5 ( \pm 29.9$)$ min in ABD, $44.4( \pm 27)$ min in ORT, $42.2( \pm 23.2)$ min in ART and 39 ( \pm 14.7$)$ min in MIX group. Average number of attempts $\left(A_{s l}\right)$ to stand was $1.8( \pm 0.8)$ in ABD group, $3.1( \pm 4.7)$ in ORT, $1.8( \pm 1.2)$ in ART and $1.8( \pm 1.2)$ in MIX. Recovery time $\left(T_{\text {Red }}\right)$ in ABD group was 102.2 $( \pm 36.5)$ min, ORT 70.1 ( \pm 36.5$)$ min, ART 72.2 ( \pm 24.8$)$ min and MIX group $66.6( \pm 19.1)$ min. $T_{\text {Rec }}$ differed $(p<0.05)$ between ABDand other groups. Threepoint assisted recoveryfrom anesthesia showed to be a safe procedure during horses 'recovery. This method is easy to apply and well tolerated by horses regardless of the surgical procedure.
\end{abstract}

Key words: anesthesia, assistance, horses, recovery, surgery.

Recuperação anestésica assistida por corda em três pontos em equinos

RESUMO: Neste estudo foi avaliado a qualidade da recuperação anestésica de equinos através do método de recuperação assistida por três pontos. Sessenta e oito cavalos (37 fêmeas e 31 machos) de diferentes raças, idade e peso foram submetidos à anestesia geral para cirurgias abdominais - ABD ( $n=15)$, artroscopias - ART $(n=17)$, demais cirurgias ortopédicas - ORT $(n=18)$ e mistas - MIX $(n=18)$. As anestesias realizadas com isofluorano resultaram em menor tempo de recuperação $(67.4 \pm 25.7 \mathrm{~min})$, comparadas com as anestesias realizadas com

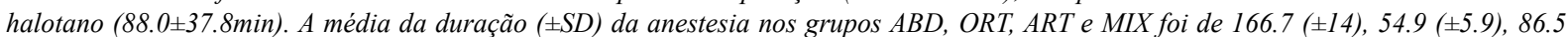
( \pm 7.3$)$ e 76.4 ( \pm 32.5 ) minutos (min) respectivamente. A qualidade da recuperação não foi influenciada pelo tempo de anestesia ou pelo uso de analgésicos, sedativos elou outras drogas anestésicas ( $>>0.05)$. A média do tempo para estação $\left(T_{E s}\right)$ durante a recuperação anestésica foi de 67.5 ( \pm 29.9$)$ min em ABD, 44.4 ( \pm 27$)$ min em ORT, 42.2 ( \pm 23.2$)$ min em ART e 39 ( \pm 14.7$)$ min em MIX. O tempo de recuperação (T $\left.T_{R e d}\right)$ em ABD foi de 102.2 ( \pm 36.5$) \mathrm{min}$, ORT 70.1 ( \pm 36.5$) \mathrm{min}$, ART $72.2( \pm 24.8)$ min e MIX $66.6( \pm 19.1)$ min. $O T_{\text {Rec }}$ diferiu $(p<0.05)$ entre o grupo de cirurgias $A B D$ e os demais. O método de recuperação anestésica por três pontos mostrou ser seguro em cavalos, sendo facilmente aplicável e bem tolerado por cavalos após diferentes procedimentos cirúrgicos.

Palavras-chave: anestesia, assistência, equinos, recuperação, cirurgia.

\section{INTRODUCTION}

General anesthesia in horses is accompanied by considerable risk and the recovery period is considered a critical phase because any problem that occurred during induction and maintenance can become evident at this moment and could impair the recovery quality (TAFFAREL et al., 2017; TEIXEIRA NETO, 2000). The reported mortality related to anesthesia recovery ranges from $0.12 \%$ (BIDWELL et al., 2007) to
1\% (DUGDALE \& TAYLOR, 2016), with bone fractures and myopathy/neuropathy being the major fatal complications (DUGDALE \& TAYLOR, 2016; JOHNSTON et al., 2002).

Studies about mortality associated with equine anesthesia identified a variety of risk factors which can be controlled and help to reduce mortality associated with this procedure (DUGDALE \& TAYLOR, 2016). In the last decades many methods have been developed to assist horses during recovery from general anesthesia, mainly from orthopedic 
procedures (WILDERJANS, 2004), decreasing the incidence and severity of complications (DRIESSEN, 2005). However, it is a common sense that none of these recovery techniques is completely safe and eliminates the risks of accidents (BIDWELL et al., 2007; DRIESSEN, 2005).

Anesthesia recovery techniques may include simple methods such as the use of trained personnel inside the recovery room to assist the horse manually, the use of ropes on the head and tail and modified floors (air cushion drainage system) (DRIESSEN, 2005). Rope-assisted recovery techniques seem to be gaining popularity, even with the assessment of rope-assisted recovery losses not being reported in a Confidential Enquiry of Perioperative Equine Fatalities (CEPEF) (DUGDALE \& TAYLOR, 2016). WILDERJANS (2004) recommends the use of two ropes due to the possibility of applying this method in any recovery room with only one manipulator and it has minimal maintenance costs. Rope-assisted recovery are thought to support and stabilize the horse through the head and tail ropes until it can stand steady without help and regain the muscular strength (WILDERJANS, 2004).

Knowing the risks and complications of equine anesthetic recovery and the difficulty of access to recovery methods in view of the reality reported in some veterinary hospitals, a methodology that associates existing methods was evaluated. The aim of this study was to describe quantitative and qualitative aspects of the three-point assisted recovery method from anesthesia in horses submitted to different surgical procedures.

\section{MATERIALS AND METHODS}

\section{Animals/Horses}

Anesthesia recovery records of 68 horses (37 females and 31 males) of different breeds and ages were reviewed. Animals were separated in groups according to the surgical procedure performed under general inhalation anesthesia: abdominal surgeries - ABD $(n=15)$, arthroscopies - ART $(n=17)$, other orthopedic surgeries - ORT $(n=18)$ and a mixed group - MIX ( $\mathrm{n}=18)$ which were composed by elective surgeries like reduction of umbilical hernias, castration, sarcoid removal, upper airway surgery and reduction of cervix laceration.

\section{Anaesthesia}

Horses received pre-anesthetic medication based on xylazine ( 0.5 to $1.1 \mathrm{mg} / \mathrm{kg}^{-1}$, depending on the patient's temperament) and acepromazine $\left(0.05 \mathrm{mg} / \mathrm{kg}^{-1}\right)$ and anesthesia was induced with ketamine $\left(3 \mathrm{mg} / \mathrm{kg}^{-1}\right)$ and diazepan $\left(0.01 \mathrm{mg} / \mathrm{kg}^{-1}\right)$. Anesthetic maintenance was performed in a semiclosed circle rebreathing system with halothane $(n=31)$ or isoflurane $(n=37)$.

\section{Anesthesia recovery}

In this assisted recovery method horses were placed in lateral recumbency with the back against one side of the padded room with the head and hind limbs direct to the surgical and preparation rooms respectively. Two ropes were tied at each side of the halter, placed on top of the helmet, and passed through the rings positioned at 2.25 meters height in the respective sidewall of the recovery room (Figure 1). Then the ropes were passed through

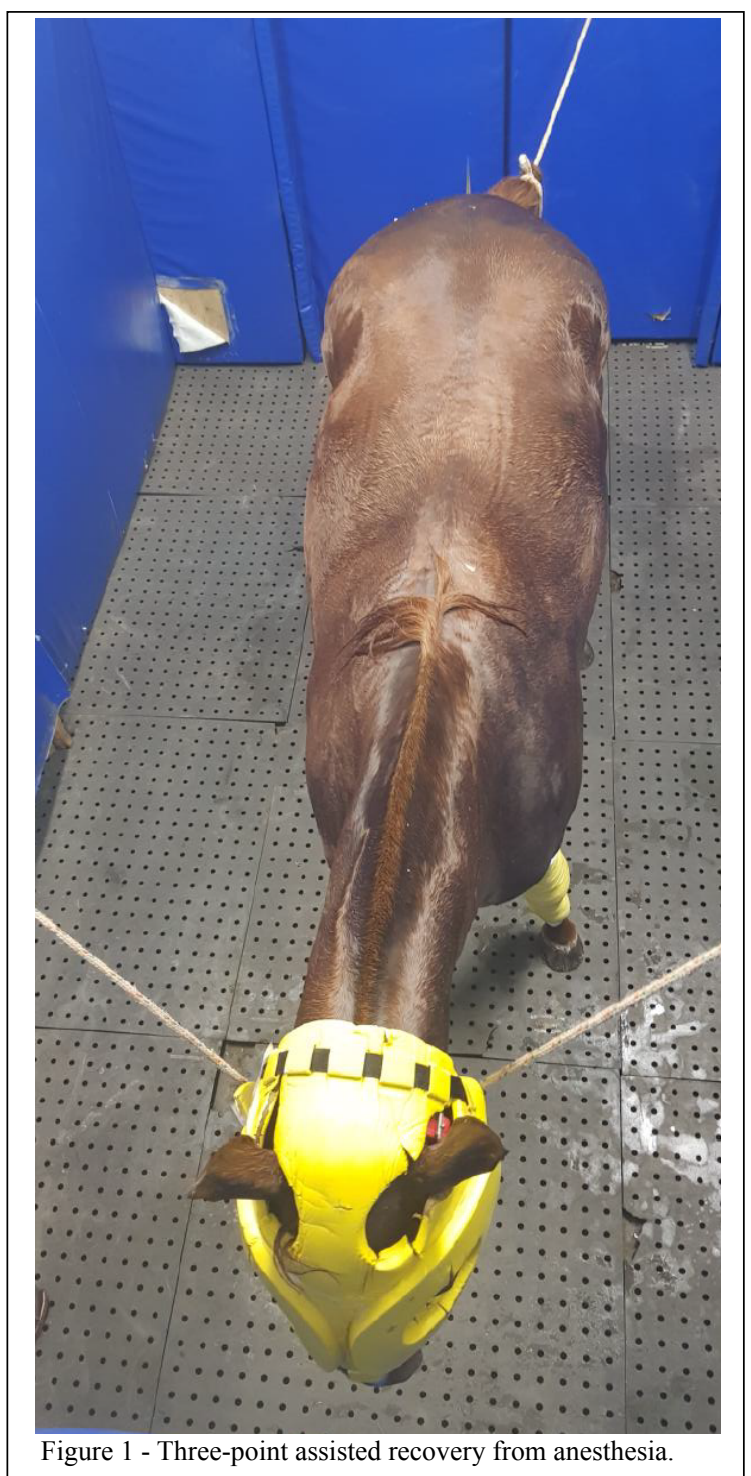


one of the door windows and held by an assistant in the preparation room. A third rope was tied to the animal's tail, passed through the second window and held by another assistant. The recovery room used for all anesthesia recoveries measured 2.60 meters wide by 3.65 meters long and had padded walls, non-slip rubber floor and an external door with two small windows to allow observation and assistance of the horses.

\section{Experimental design}

Parameters such as gender, age, breed, position of the horse on the table during surgery, anesthetic protocol (AP), surgical procedure (PC), time of anesthesia from induction to disconnection of the anesthesia equipment (AT), time to stand $\left(\mathrm{T}_{\mathrm{st}}\right)$, number of attempts to stand $\left(\mathrm{A}_{\text {st }}\right)$ and recovery time (from the end of anesthesia to being back at the stall) $\left(T_{\text {Rec }}\right)$ were recorded for each horse. The American Society of Anesthesiologists (ASA) physical status classification system was used and eventual observations (if supportive therapy was required and analgesics or sedatives were given during recovery) according to the situation (DAABISS, 2011) were also included. Recovery quality was subjectively evaluated using a modified Donaldson's et. al (2000) method which considers behavioral observations as sternal phaseadoption or no sternal recumbence, number of attempts to get up, help needed in the recovery room and complications during anesthetic recovery. Status of the horse in the recovery room environment was scored to create a recovery-conditions score: presence of sternal phase (1- yes; 2 - no), number of attempts to stand (1- three or less; 3 - four or more), help needed in the recovery room (1-no; 3-yes) and complications in anesthetic recovery (1-no; 3-yes). Scores related to quality of anesthesia were attributed in a way that score 1 represents an optimal situation for a quiet and safe anesthetic recovery, scores 2 and 3 can indicate complications in recovery. The sum of scores from 4 to 8 identifies a high quality anesthetic recovery, while values from 9 to 11 a low quality recovery.

\section{Statistic analysis}

Non-parametric data were analyzed by Kruskal-Wallis and correlation test. The variables AT, Tst and TRec were submitted to parametric analysis (ANOVA followed by Tukey Test). The difference was considered significant when $\mathrm{p}<0.05$.

\section{RESULTS AND CONCLUSION}

The three-point assisted anesthesia recovery provided a safe recovery without any catastrophic injury even in complex surgical cases that required prolonged AT or those associated with animals in poor systemic condition (ASA IV and $\mathrm{V})$. There were no deaths that could be related to the recovery method employed. The parameters evaluated are presented according to the surgery group in the table 1.

The mean age of horses from ABD, ORT, ART and MIX groups was $7( \pm 4), 4.1( \pm 3.3), 2.5( \pm 0.8)$ and $4.1( \pm 3)$ years respectively, and no influence of age on anesthesia recovery quality was observed among groups $(p>0.05)$. However, a positive correlation between age and $\mathrm{T}_{\text {Rec }}$ was observed in Criollo $(\mathrm{r}=17$, $\mathrm{p}<0.05)$ and Thoroughbred $(\mathrm{r}=45, \mathrm{p}<0.05)$ horses. The low age of horses $(4.3 \pm 3.3$ years) may have influenced recovery results, since increased risk of mortality is associated with older horses (JOHNSTON et al., 2002; JOHNSTON et al., 2004; DUGDALE et al., 2016) related to higher ASA classification, colic surgery and bone fractures or luxation during anesthesia recovery (DUGDALE et al., 2016 ).

Breed is also another factor that could interfere on quality of anesthetic recovery (VOULGARIS \& HOFMEISTER, 2009) since patient's size and

Table 1 - Mean and standard deviation of age, weight, duration of anesthesia (AT), time to stand up after anesthesia ( $\mathrm{T}_{\mathrm{st}}$ ), overall time for recovery from anesthesia $\left(\mathrm{T}_{\mathrm{Rec}}\right)$, attempts to stand $\left(\mathrm{A}_{\mathrm{st}}\right)$ and scores of quality recovery of horses after inhalation anesthesia submitted to abdominal, orthopedic, arthroscopic and other surgeries (mixed).

\begin{tabular}{|c|c|c|c|c|}
\hline Parameters & Abdominal $(\mathrm{n}=15)$ & Orthopedic $(\mathrm{n}=18)$ & Arthroscopies $(n=17)$ & Mixed $(n=18)$ \\
\hline Age (years) & $7 \pm 4$ & $4.1 \pm 3.3$ & $2.5 \pm 0.8$ & $4.1 \pm 3$ \\
\hline Weight (kg) & $495 \pm 101$ & $460.44 \pm 75.8$ & $499.76 \pm 31.3$ & $446.67 \pm 95.4$ \\
\hline AT (minutes) & $166.7 \pm 14^{\mathrm{a}}$ & $54.94 \pm 5.9^{\mathrm{b}}$ & $86.53 \pm 7.3^{b}$ & $76.4 \pm 32.5^{\mathrm{b}}$ \\
\hline $\mathrm{A}_{\mathrm{st}}$ & $1.8 \pm 0.8$ & $3.1 \pm 4.7$ & $1.8 \pm 1.2$ & $1.8 \pm 1.1$ \\
\hline $\mathrm{T}_{\mathrm{st}}$ (minutes) & $67.5 \pm 29.9^{\mathrm{a}}$ & $44.44 \pm 27^{\mathrm{b}}$ & $42.2 \pm 23.2^{\mathrm{b}}$ & $39 \pm 14.7^{b}$ \\
\hline $\mathrm{T}_{\mathrm{Rec}}$ (minutes) & $102.2 \pm 36.5^{\mathrm{a}}$ & $70.11 \pm 36.5^{b}$ & $72.2 \pm 24.8^{b}$ & $66.6 \pm 19.1^{b}$ \\
\hline Quality recovery scores & $4.5 \pm 5,2$ & $5 \pm 1.2$ & $4.9 \pm 1.7$ & $4.9 \pm 1.3$ \\
\hline
\end{tabular}

Ciência Rural, v.48, n.11, 2018. 
temperis related with injury risk at anesthesia recovery (WILDERJANS, 2004). In the presented study, horses of hot blood temper, mainly young Thoroughbred, showed excitement after administration of the preanesthetic and induction medications and also presented a worse recovery characterized by excitement and several frustrated attempts to rise. Horses with nervous temperament normally present a shorter recovery time which does not imply in better recovery quality (VOULGARIS \& HOFMEISTER, 2009), since they get up too soon after the end of anesthesia may still have residual effects of the anesthetics that produce some musculoskeletal incoordination (BIDWELL et al, 2007).

The position of horses during surgery procedures did not alter the recovery time with the exception of one mare from the MIXgroup that remained in Trendelenburg position for correction of a cervix laceration. This mare presented post-anesthetic myopathy of the gluteal region, probably due to poor positioning and cushioning on the surgical table (DUGDALE \& TAYLOR, 2016). Long anesthetic procedures, even in lateral recumbency, have been associated with anesthetic recovery failures and postanesthesic myopathy. Post-anesthetic myopathy is considered an important risk factor for occurrence of fractures during anesthesia recovery, due to pain, muscle weakness and incoordination (DUGDALE \& TAYLOR, 2016). Other complications that may occur during anesthetic recovery include skeletal fractures, spinal cord malacia, post-anaesthetic neuropathies and post-anaesthetic respiratory obstructions (JOHNSTON et al, 2002; WAGNER, 2008; DUGDALE \& TAYLOR, 2016).

Isoflurane, as expected, was superior to halothane in both maintenance and anesthetic recovery time $(\mathrm{p}<0.05)$. Animals anesthetized with isoflurane $(n=37)$ recovered faster $(67.4 \pm 25.7 \mathrm{~min})$ than those with halothane $(n=31)(88.0 \pm 37.8 \mathrm{~min})$. This did not reflect on quality of recovery, since some horses attempted to get up before they had completely regained motor control over their body increasing the need for support from the three ropes. The present study corroborates the statements of CORNICK-SEAHORN (2004) and BETTSCHARTWOLFENSBERGER \& LARENZA (2007), who claimed that anesthetic maintenance with isoflurane provides faster recovery than halothane; however, recovery from anesthesia was not better and in some cases was even worse than those with halothane if the number of attempts to get up of the isofluraneanesthetized animals was considered.

The surgical procedure did not influence the recovery quality, but $\mathrm{ABD}$ group presented longer anesthesia (166.7 $\pm 14 \mathrm{~min})$ and recovery $(102.2 \pm 36.5 \mathrm{~min})$ time compared to the other groups $(p<0.05)$. Horses with gastrointestinal disorders, as expected, presented higherASA(IV and IV) associated with systemic complications like dehydration, hemoconcentration and endotoxemia that could prolong $\mathrm{T}_{\mathrm{Rec}}$, without affecting the recovery quality in most cases (JOHNSTON et al, 2002; MOSLEY, 2015). Four patients from this group presented an anesthesia $\mathrm{T}_{\text {Rec }}$ of more than two hours, and one of them had a low recovery quality presenting ataxia and agitation, turning assistance with the ropes during standing attempts difficult. Thus, these patients suffer a higher risk of fatality after anesthesia.

The anesthesia time in the ABD group (166.7 $\pm 14 \mathrm{~min})$ was different from ORT $(54.9 \pm 5.9 \mathrm{~min})$, ART (86.5 $\pm 7.3 \mathrm{~min})$ and MIX (76.4 $\pm 32.5 \mathrm{~min})$ groups. The accumulation of inhaled anesthetic agent in the brain and other tissues is a consequence of increasing AT requiring a longer period for the patient to regain consciousness, musculoskeletal coordination and strength to get up (WAGNER, 2008; DUGDALE \& TAYLOR, 2016). However, recovery quality was not influenced by AT as previously described (TEIXEIRA NETO, 2000) even in horses from the ABD group. This difference may be explained by the recovery method used in the present study that enabled horses to remain in the recovery room without exposure to any visual and auditory stimuli; therefore, allowing them to stay recumbent a longer time to clear the anesthetic agents from the organism and returning to consciousness in better conditions.

Horses that remained in sternal recumbency for a longer period of time showed better recovery quality, since after remaining a period in this position they usually perform a unique and successful attempt to raise (GROSENBAUGH \& MUIR, 1998). Most recovery problems occur when horses try to get up too soon after anesthesia ends (HUBBEL, 2004). In order to minimize this problem, an alpha-2 adrenergic agonist, such as xylazine, represents a therapeutic option to be used during or right after the end of anesthesia making the recovery of consciousness a slower process (GROSENBAUGH \& MUIR, 1998; WAGNER, 2008).

The mean number $( \pm \mathrm{SD})$ of attempts to rise was $1.8( \pm 0.8), 3.1( \pm 4.7), 1.8( \pm 1.2), 1.8( \pm 1.17)$ in the ABD, ORT, ART andMIX groups, respectively. There was no difference $(p>0.05)$ in the number of attempts to stand up between groups. However, one patient from ORT group presented worse recovery quality, which was attributed to excitement, pain and to the cast immobilization of the limb that turned standing on that limb more difficult. Those factors 
may have contributed to horses trying to get up earlier, making the recovery more violent and increasing the risk of traumas or fractures (TEIXEIRA NETO, 2000). The average $T_{\text {st }}$ during recovery was 67.5 $( \pm 29.9), 44.4( \pm 27.0), 42.2( \pm 23.2)$ and $39.0( \pm 14.7)$ min for animals of the ABD, ORT, ART and MIX groups, respectively, the $\mathrm{T}_{\mathrm{st}}$ differed $(\mathrm{p}>0,05)$ from the $\mathrm{ABD}$ group to the others, probably due to the longer anesthesia to which these animals were submitted.

Mean anesthesia $T_{\text {Rec }} \quad(93,2 \pm 54 \mathrm{~min})$ observed in the present study was similar to the one report using other standard recovery techniques, like the Anderson Sling method (82min) on high risk orthopedic surgeries anesthetized with isoflurane or desflurane (TAYLOR et al., 2005) and lower than the one observed with the hydromassage pool recovery system (108min) after anesthesia with isoflurane, halothane and sevofluorane (TIDWELL et al., 2002).

In order to avoid pain in the postanesthetic period a good intraoperative analgesic plan is mandatory since pain can lead to standing attempts, ataxia and incoordination, with inadequate muscle strength, negatively influencing recovery (WILDERJANS, 2004; TAFFAREL et al., 2017). Moreover, the use of higher doses of sedative drugs has also been associated with lower $\mathrm{T}_{\mathrm{Rec}}$ with superior recovery quality (VOULGARIS \& HOFMEISTER, 2009). Howewer, analgesia with opioid drugs (CLARK et al., 2008; VOULGARIS \& HOFMEISTER, 2009), flunixin meglumine and dipyrone did not influence recovery time and quality in some studies (TAFFAREL et al., 2017). In this study, a prolonged $\mathrm{T}_{\mathrm{Rec}}$ was observed in horses that received analgesics, sedatives or anesthetic drugs during or at the end of anesthesia, but no difference in recovery quality was observed when compared to horses that did not receive any type of drug. The horses presented a longer recovery time when sedatives and tranquilizers were associated with preanesthetic medication and before the extubation. Different surgical procedures associated with different anesthetic protocols might explain the distinctive results observed in several published studies; as observed here DUGDALE \& TAYLOR (2016) also reported that, opposed to expected, low doses of sedative alone resulted in lower recovery time, which in some cases decreased the recovery quality.

The scale of anesthetic recovery quality of DONALDSON et al. (2000) was changed so that the items evaluated demonstrated the effectiveness and safety of the anesthetic recovery method in a clear and succinct manner. The scale was efficient in the analysis of anesthesic recoveries with good or poor quality. Only three animals showed scores between 9 and 11, suggesting that the three-point rope assisted anesthesia recovery method was efficient.

The author's believe that the advantage of this method, compared with the two-point ropes, is that it allows the horse to be kept standing without extending the horse's head too much, which can cause discomfort and unbalance the animal. The overall complication rate observed in anesthetic recovery during this study was $4.41 \%(n=3)$. One case was a luxation of the distal interphalangeal joint and two cases that presented myopathy signs. Our results, even with a smaller number of horses, are close to those published by WILDERJANS (2004), who reported 7000 recoveries and complication rates near to zero with the use of a two-point assisted recovery. TIDWELL et al. (2002) described higher complications rates with hydromassage pool recovery $(\mathrm{n}=60)$, like pulmonary edema $(17 \%)$, skin abrasions $(3 \%)$, incisional infection (3\%), cellulitis and septic arthritis $(2 \%)$. The three-point assisted recovery method proposed was considered adequate in providing a safe recovery for horses without any fatal accident. Following some basic safety guidelines, assisted recovery with the use of a rope on the tail and two on the head is easy to apply and safe for horse and handlers.

\section{CONCLUSION}

The three-point assisted recovery method for anesthesia demonstrated to be well tolerated by horses of different ages submitted to different surgical procedures.

\section{ACKNOWLEDGEMENTS}

This study was sponsored by Coordenação de Aperfeiçoamento de Pessoal de Nível Superior (CAPES) and the Universidade Federal de Santa Maria (UFSM/Fatec CT.123/2014).

\section{CONFLICTS OF INTEREST}

The authors declare no conflict of interest. The founding sponsors had no role in the design of the study; in the collection, analyses, or interpretation of data; in the writing of the manuscript, and in the decision to publish the results.

The authors contributed equally to the manuscript.

\section{REFERENCES}

BETTSCHART-WOLFENSBERGER， R.; LARENZA， MP. Balanced anesthesia in the equine. Clinical Techniques in Equine Practice, v.6, p.104-110, 2007. Available from: <https://doi. 
org/10.1053/j.ctep.2007.05.002>. Accessed: Nov. 18, 2013. doi: $10.1053 /$ j.ctep. 2007.05 .002

BIDWELL, L.A. et al. Equine perioperative fatalities associated with general anaesthesia at a private practice--a retrospective case series. Veterinary Anaesthesia and Analgesia, v.34, p.23-30, 2007. Available from: <https://doi.org/10.1111/j.1467-2995.2005.00283. x>.Accessed:Dec. 10,2017.doi: 10.1111/j.1467-2995.2005.00283.x.

CLARK, L. et al. The effects of morphine on the recovery of horses from halothane anaesthesia. Veterinary Anaesthesia and Analgesia, v.35, p.22-29, 2008. Available from: <https://doi.org/1 0.1111/j.1467-2995.2007.00350.x>. Accessed: Nov. 18, 2013. doi: 10.1111/j.1467-2995.2007.00350.x.

CORNICK-SEAHORN, J. Anesthesia of the critically ill equine patient Veterinary Clinic North America Equine Practice, v. 20, p.127-149, 2004. Available from: <https://doi.org/10.1016/j.cveq.2003.12.008> Accessed: Nov. 18, 2013. doi: 10.1016/j.cveq.2003.12.008

DAABISS, M. American society os anaesthesiologists physical status classification. IndianJournal of Anaesthesiology, v.55,p.111-115,2011 Available from: <https://dx.doi.org/10.4103\%2F0019-5049.79879>. Accessed: Sept. 15, 2017. doi: 10.4103\%2F0019-5049.79879.

DRIESSEN, B. Assisted recovery in horses awakening from general anesthesia. In: STEFFEY. E.P. (ed.) Recent advances in anesthetic management of large domestic animals. International Veterinary Information Service, USA, 2005.

DONALDSON, L.L. et al. The recovery of horses from inhalant anesthesia: A comparison of halothane and isoflurane. Veterinary Surgery, v.29, p.92-101, 2000. Available from: <https://doi. org/10.1111/j.1532-950X.2000.00092.x>. Accessed: Nov. 18, 2013. doi: 10.1111/j.1532-950X.2000.00092.x.

DUGDALE, A.H.A.; TAYLOR, P.M. Equine anaesthesiaassociated mortality: where are we now? Veterinary Anaesthesia and Analgesia, v.43, p.242-255, 2016. Available from: <https:// doi.org/10.1111/vaa.12372>. Accessed: Aug. 16, 2016. doi: 10.1111/vaa.12372.

DUGDALE, A.H.A. et al. Twenty years later: a single-centre, repeat retrospective analysis of equine perioperative mortality and investigation of recovery quality. Veterinary Anaesthesia and Analgesia, v.43, p.171-178, 2016. Available from: <https://doi. org/10.1111/vaa.12285>. Accessed: Aug. 16, 2016. doi: 10.1111/ vaa. 12285 .

GROSENBAUGH, D.A.; MUIR, W.W. Cardiorespiratory effects of sevoflurane, isoflurane, and halothane anesthesia in horses. American Journal of Veterinary Research, v. 59, p.101-106, 1998. Available from: <https://www.ncbi.nlm.nih.gov/pubmed/9442252>. Accessed: Aug. 16, 2016.

HUBBEL, J.A.E. Anesthesia of the horse: monitoring, recovery, and complications. In: 50TH ANNUAL CONVENTION OF THE AMERICAN ASSOCIATION OF EQUINE PRACTITIONERS, 2004, Denver, Colorado. Proceedings... Denver: AAEP, 2004. p.1447-1204.
JOHNSTON, G.M.et al. The confidential enquiry into perioperative equine fatalities (CEPEF): mortality results of Phases 1 and 2. Veterinary Anaesthesia and Analgesia, v.29, p.159-170, 2002. Available from: <https://doi.org/10.10 46/j.1467-2995.2002.00106.x>. Accessed: Nov. 20, 2013. doi: 10.1046/j.1467-2995.2002.00106.x.

JOHNSTON, G.M.et al. Is isoflurane safer than halothane in equine anaesthesia? Results from a prospective multicentre randomised controlled trial. Equine Veterinary Journal, v.36, p.64-71, 2004. Available from: <https://doi.org/10.2746/0425164044864723>. Acessed: Aug. 11, 2016. doi: 10.2746/0425164044864723.

MOSLEY, C. Anesthetic considerations for equine colic. In: THE NORTH AMERICAN VETERINARY CONFERENCE, 2005, Orlando, Florida. Proceedings... Orlando: NAVC, 2005.

TAFFAREL, M.O.et al. Pre-emptive analgesia, including morphine, does not affect recovery quality and time in either painfree horses or horses undergoing orchiectomy. Journal of Equine Veterinary Science, v.48, p.82-85, 2017. Available from: $<$ https:// doi.org/10.1016/j.jevs.2016.03.015>. Accessed: Aug. 7, 2016. doi: 10.1016/j.jevs.2016.03.015.

TAYLOR, E.L. et al. Use of the Anderson sling suspension system for recovery of horses from general anesthesia. Veterinary Surgery, v.34, p.559-564, 2005. Available from: <https://doi. org/10.1111/j.1532-950X.2005.00088.x>. Accessed: Nov. 20, 2013. doi: 10.1111/j.1532-950X.2005.00088.x.

TEIXEIRA NETO, F.J. Complicações associadas a anestesia geral em equinos: diagnóstico e tratamento parte II. Revista de educação continuada em medicina veterinária e zootecnia, v.3, p.24-28, 2000. Available from: <http:// revistas.bvs-vet.org.br/recmvz/article/view/3366>. Accessed: Mar. 14, 2014.

TIDWELL, S.A. et al. Use of a hydro-pool system to recover horses after general anesthesia: 60 Cases. Veterinary Surgery, v.31, p.455-461, 2002. Available from: <https://doi.org/10.1053/ jvet.2002.34662>. Accessed: Nov. 22, 2013. doi: 10.1053/ jvet.2002.34662.

VOULGARIS, D.A.; HOFMEISTER, E.H. Multivariate analysis of factors associated with post-anesthetic times to standing in isoflurane-anesthetized horses: 381 cases. Veterinary Anaesthesia and Analgesia, v.36, p.414-420, 2009. Available from: $<$ https:// doi.org/10.1111/j.1467-2995.2009.00472.x>. Accessed: Nov. 22, 2014. doi: 10.1111/j.1467-2995.2009.00472.x.

WAGNER, A.E. Complications in equine anesthesia. Veterinary Clinic North America Equine Practice, v.24, p.735-752, 2008. Available from: <https://doi.org/10.1016/j.cveq.2008.10.002>. Accessed: Nov. 22, 2014. doi: 10.1016/j.cveq.2008.10.002.

WILDERJANS, H. Advances in assisted recovery from anaesthesia in horses with fractures. In: 12TH EUROPEAN SOCIETY OF VETERINARY ORTHOPAEDICS AND TRAUMATOLOGY, 2004, Munich, Germany. Proceedings...Munich: ESVOT, 2004. p.201-202. 